\title{
PERAN ORANG TUA TERHADAP KETERAMPILAN MENYIKAT GIGI DAN MULUT PADA ANAK DISABILITAS INTELEKTUAL
}

\author{
Leny Pratiwi Arie Sandy \\ Program Studi Higiene Gigi, Fakultas Kedokteran Gigi \\ Universitas Gadjah Mada \\ Email:leny.pratiwi.a@ugm.ac.id
}

\begin{abstract}
Intellectual disability is a group of children with impaired intellectual function below an average of 70 or lower. This group experienced problems in terms of self-development skills such as tooth brushing. Tooth brushing is an activity the mechanical removal of from food scraps, germs and plaque. Growing and developing independence of children with intellectual disability was influenced by the role of parents. Parents who have a role as basic of children behavior was contributed to process child growth. This study aims to determine the relationship of parental role to the tooth brushing skill in intellectual disability children.

This research method is analytic survey and used cross sectional design. Sampling technique using total sampling. The population in this research is intellectual disability children in SLB Pamardi Putra Banguntapan Bantul Yogyakarta as many as 30 people. The role of parent was measured using questionnaire and tooth brushing skills measured using check list (from Special Care Advocates in Dentistry (SAID) Guidelines, 1995). Data analysis using Spearman correlation with significance level $(0,05)$. The result of this research is $p=0.185(>0.05)$, it shows that there is no significant correlation between parent role to oral and brushing skills in intellectual disability children in SLB Pamardi Putra Banguntapan Yogyakarta.
\end{abstract}

Keyword: Intellectual Disability; The Role of Parent; Tooth Brushing Skill.

\begin{abstract}
ABSTRAK
Disabilitas intelektual merupakan kelompok anak yang mengalami gangguan fungsi intelektual dibawah rata-rata antara 70 atau lebih rendah. Kelompok ini mengalami permasalahan dalam hal keterampilan bina diri seperti menyikat gigi. Menyikat gigi merupakan kegiatan yang dilakukan secara mekanik untuk menghilangkan sisa makanan, kuman dan plak. Pertumbuhan dan perkembangan kemandirian anak disabilitas intelektual dipengaruhi oleh peran orang tua. Orang tua yang memiliki peran sebagai peletak dasar perilaku anak memberikan andil terhadap proses tumbuh kembang anak. Penelitian ini bertujuan untuk mengetahui hubungan peran orang tua terhadap keterampilan menyikat gigi dan mulut pada anak disabilitas intelektual.

Metode penelitian yaitu survei analitik dan rancangan yang digunakan yaitu cross sectional. Tehnik pengambilan sampel menggunakan total sampling. Populasi dalam penelitian ini yaitu anak disabilitas intelektual di SLB Pamardi Putra Banguntapan Bantul Yogyakarta sebanyak 30 orang. Alat ukur penelitian yaitu kuesioner peran orang tua dan keterampilan menggosok gigi diukur menggunakan check list (dari pedoman Special Care Advocates in Dentistry (SAID), tahun 1995). Analisis data menggunakan korelasi Spearman dengan taraf signifikansi $(0,05)$. Hasil penelitian didapatkan nilai $p=0.185(>0.05)$, hal ini menunjukkan bahwa tidak terdapat hubungan antara keterampilan menyikat gigi dan mulut pada anak disabilitas intelektual di SLB Pamardi Putra Banguntapan Yogyakarta.
\end{abstract}

Kata Kunci: Disabilitas Intelektual; Keterampilan Menyikat Gigi dan Mulut; Peran Orang Tua. 


\section{PENGANTAR}

Disabilitas intelektual (disingkat menjadi DI) merupakan salah satu pengkategorian anak berkebutuhan khusus dimana pada kondisi ini anak memiliki tingkat kecerdasan di bawah rata-rata. Menurut Diagnostic and Statistical Manual of Mental Disorders (DSM-5) tahun 2012 disabilitas intelektual merupakan suatu gangguan selama periode perkembangan, ditandai dengan defisit fungsi intelektual, adaptif, sosial dan praktis. Disabilitas intelektual mengalami hambatan dalam keterbatasan melakukan aktivitas fisik, kesulitan sensorik, dan cacat fisik yang menyolok. Keterlambatan lain yang sering menyertai antara lain seperti duduk, merangkak, berdiri, berjalan sendiri (Selikowitz M. 2001). Di Indonesia penderita anak DI sedang mencapai 1-3\% dari jumlah penduduk keseluruhan. Insiden tertinggi terjadi pada masa anak sekolah dengan puncak umur 10-14 tahun. Kelompok ini terjadi pada kelompok laki-laki 1.5 kali lebih banyak dibandingkan pada kelompok perempuan (Kay, J. dan Tasman, A. 2006).

Orang tua anak DI memiliki tanggung jawab dalam melatih, mendidik anak dalam proses perkembangan anak, selain itu berperan dalam mengembangkan perilaku adaptif sosial (Lumbantobing, 2008). Peranan orang tua dalam mendidik anak yaitu memberikan dasar pendidikan, sikap, watak dan keterampilan dasar seperti agama, budi pekerti, sopan santun, estetika, kasih sayang, rasa aman serta menanamkan kebiasaan yang baik, dan disiplin (Idris dan Jamal, 1992). Menurut Notoatmodjo (2003) orang tua merupakan peletak dasar perilaku anak karena orang tua merupakan sasaran utama dalam promosi kesehatan masyarakat.

Orang tua memberikan pengaruh terhadap perkembangan dan kemandirian terhadap anak. Orang tua yang memiliki anak disabilitas intelektual berperan dalam mendidik dan melatih anak dalam proses perkembangan. Anak disabilitas intelektual sebagian besar mengalami keterbatasan fisik dan motorik, kondisi ini menyebabkan pemenuhan kebutuhan perawatan diri pada kelompok ini mengalami kendala (Smeltzer, 2002). Perawatan diri (personal hygiene) dilakukan untuk mempertahankan kesehatan baik secara fisik maupun psikologis, salah satu kegiatan perawatan diri yang dilakukan yaitu menggosok gigi.

Kegiatan menyikat gigi merupakan salah satu upaya pencegahan terhadap resiko terkena penyakit gigi dan mulut. Menyikat gigi sebagai cara yang efektif dalam membersihkan plak gigi (Apiou dkk, 1994). Salah satu faktor yang mempengaruhi efektivitas membersihkan plak gigi yaitu ketelitian dalam menyikat gigi ditiap permukaan (Sriyono, 2007). Ketelitian dalam menggosok gigi diperlukan kemampuan atau keterampilan tangan individu yang baik saat menyikat gigi. Hal ini menjadi suatu permasalahan pada kelompok anak DI karena sebagian besar kelompok ini memiliki masalah pada kemampuan motorik tangan. Keterbatasan fisik yang dialami oleh anak disabilitas intelektual akan mempengaruhi terhambatnya upaya dalam melakukan kegiatan menyikat gigi. Kelompok anak berkebutuhan khusus termasuk kelompok anak yang memiliki resiko tinggi terhadap penyakit gigi dan mulut.

Hasil survei yang dilakukan oleh Kumar dkk (2009) di India mengenai kondisi kesehatan gigi dan mulut anak retardasi mental sebanyak 117 anak yang diperiksa. Didapatkan data sebesar $67,6 \%$ status kebersihan gigi dan mulut pada kelompok ini termasuk kriteria rendah dan $66,4 \%$ terdapat poket periodontal. Loureiro, A. dkk (2007) juga melakukan survei kesehatan gigi dan mulut pada anak retardasi mental di Brazil. Didapatkan data dari 93 anak yang diperiksa, 91\% mengalami gingivitis dan $33 \%$ mengalami periodontitis. Hasil kajian yang dilakukan oleh Istiqomah dkk (2016) menunjukkan bahwa anak tunagrahita di Kota Semarang sebanyak 83,2\% mengalami karies gigi. Data-data tersebut menunjukkan bahwa kelompok anak berkebutuhan khusus rentan terhadap penyakit gigi dan mulut. 
Risiko terhadap penyakit gigi dan mulut yang tinggi pada kelompok anak disabilitas intelektual diperlukan upaya pencegahan yang efektif untuk mengurangi risiko. Kegiatan menyikat gigi sebagai salah satu upaya pencegahan yang murah dan mudah dilakukan. Keterlibatan orang tua dan pengasuh dalam melatih keterampilan menyikat gigi dan mulut memiliki peran tersendiri dalam hal ini. Berdasarkan latar belakang tersebut peneliti menjadi tertarik untuk mengkaji lebih dalam peran orang tua terhadap keterampilan menyikat gigi dan mulut pada anak disabilitas intelektual. Penelitian ini dilakukan di SLB Pamardi Putra yang terletak di daerah Banguntapan Bantul Yogyakarta.

\section{METODE}

Jenis penelitianiniyaitu surveianalitik, dan rancangan yang digunakan yaitu cross sectional. Penelitian ini telah mendapatkan persetujuan dari Tim Etik Penelitian Fakultas Kedokteran Gigi UGM No.345/KKEP/FKG-UGM/ EC/2012. Pengambilan sampel menggunakan Total Sampling. Populasi penelitian ini yaitu seluruh anak disabilitas intelektual di SLB Pamardi Putra Banguntapan Bantul Yogyakarta sebanyak 30 anak. Kriteria subyek dalam penelitian ini yaitu anak disabilitas intelektual ringan dan sedang (mampu didik dan mampu latih), tidak mengalami kecacatan ekstremitas atas dan bawah serta kebutaan, tinggal dirumah tidak tinggal di asrama. Alat ukur penelitian yaitu kuesioner peran orang tua dan untuk mengukur keterampilan menggosok gigi yaitu check list (dari pedoman Special Care Advocates in Dentistry (SAID), tahun 1995). Nilai keterampilan menggosok gigi dapat dibedakan dalam tiga kategori yaitu: kategori buruk 0-46, kategori sedang 47-92, kategori baik 93-138. Nilai yang diperoleh dibuat berdasarkan penilaian acuan patokan (PAP) yaitu menentukan nilai tertinggi dan terendah (Subekti dan Firman, 1986). Alat dan bahan penelitian yang digunakan yaitu sikat gigi, pasta gigi, gelas kumur, lembar kuesioner dan alat tulis. Analisis data menggunakan Korelasi Spearman dengan nilai signifikansi $(0,05)$.

\section{HASIL DAN PEMBAHASAN}

Hasil penelitian ini didapatkan karakteristik orang tua subyek penelitian yaitu $44,8 \%$ usia pada rentang $41-45$ tahun, latar belakang pendidikan $34 \%$ orang tua lulusan SMA (Sekolah Menengah Atas) serta pekerjaan sebagian besar $76 \%$ sebagai wiraswasta. Responden sebagian besar berjenis kelamin laki-laki 65\% dan pada rentang usia 10-13 tahun. Gambaran peran orang tua terhadap keterampilan menyikat gigi dan mulut anak disabilitas intelektual (terlihat di Gambar 1).

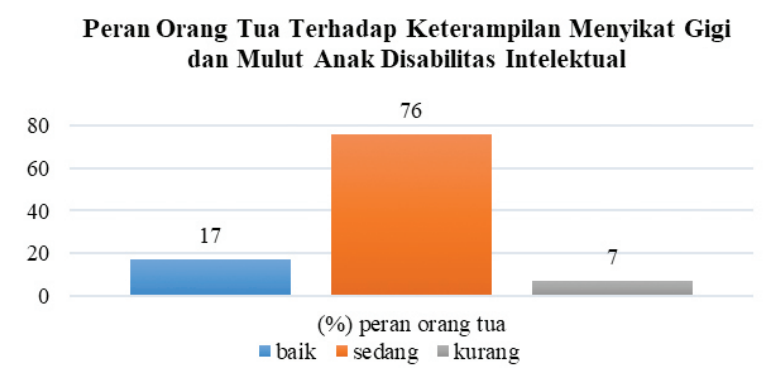

Gambar 1. Grafik Peran Orang Tua Terhadap Keterampilan Menyikat Gigi dan Mulut Anak Disabilitas Intelektual

Gambar 1 menunjukkan bahwa dari hasil penilaian peran orang tua anak disabilitas intelektual di SLB Pamardi Putra Banguntapan Bantul Yogyakarta sebagian besar sebanyak $76 \%$ pada kategori sedang. Sebanyak $7 \%$ orang tua memiliki peran pada kategori kurang.

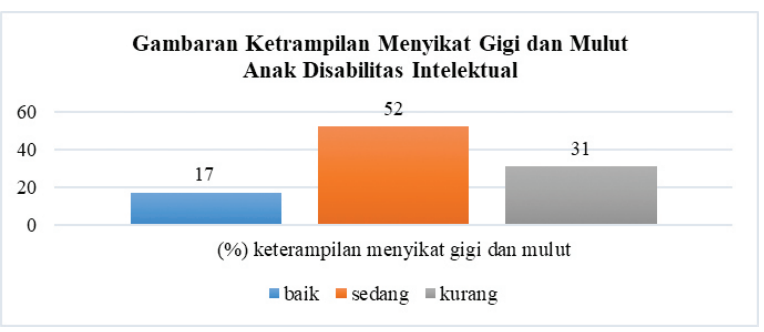

Gambar 2. Grafik Keterampilan Menyikat Gigi dan Mulut Anak Disabilitas Intelektual 
Gambar 2 menunjukkan bahwa dari hasil gambaran keterampilan menyikat gigi dan mulut anak disabilitas intelektual di SLB Pamardi Putra Banguntapan Bantul Yogyakarta sebagian besar sebanyak $52 \%$ pada kategori sedang. Keterampilan menyikat gigi dan mulut yang berkategori kurang yaitu sebesar $31 \%$.

Tabel 1. Uji Korelasi Spearman antara Peran Orang Tua Terhadap Keterampilan Menyikat Gigi dan Mulut

\begin{tabular}{lllll}
\hline & & Peran Orang Tua & \multicolumn{1}{c}{$\begin{array}{c}\text { Keterampilan Menyikat Gilut } \\
\text { anak DI }\end{array}$} \\
\hline Spearman's rho & Peran orang & Correlation & 1 & -.253 \\
& tua & Coefficient & & .185 \\
& & Sig-(2-tailed) & 30 & 30 \\
& $\mathrm{~N}$ & & \\
\hline & Keterampilan & Correlation & -.253 & 1 \\
& menyikat gilut & Coefficient & .185 & 30 \\
& & Sig-(2-tailed) & 30 & 30 \\
& $\mathrm{~N}$ & & \\
\hline
\end{tabular}

Berdasarkan Tabel 1 diperoleh nilai $p$ : 0,185 (>0,05) yang menunjukkan bahwa korelasi antara peran orang tua terhadap keterampilan menyikat gigi dan mulut pada anak disabilitas intelektual di SLB Pamardi Putra Banguntapan Bantul Yogyakarta tidak bermakna. Terlihat bahwa nilai korelasi Spearman sebesar -.253 menunjukkan korelasi yang negatif. Hal ini menunjukkan bahwa tidak terdapat hubungan antara peran orang tua terhadap keterampilan menyikat gigi dan mulut pada anak disabilitas intelektual.

Orang tua subyek penelitian sebagian besar berada pada kelompok usia 41-45 tahun $(44,8 \%)$, menujukkan sebagian besar masuk kelompok usia produktif. Tingkat pendidikan orang tua sebagian besar sudah baik, yaitu $34 \%$ lulus SMA. Tingkat pendidikan memiliki pengaruh terhadap seseorang untuk memahami dan menerima edukasi kesehatan gigi dan mulut yang baik. Orang tua yang memiliki pendidikan yang tinggi lebih mengorientasikan pada tindakan preventif, lebih tahu tentang masalah kesehatan dan status kesehatan lebih baik (Timmrect CT, 2005).

Peran orang tua yang terlihat pada (Gambar 1) menunjukkan sebagian besar orang tua memiliki peran pada kategori sedang $76 \%$. Orang tua memiliki peranan sangat penting dalam mengangkat eksistensi anak berkebutuhan khusus. Anak akan memiliki rasa percaya diri untuk beraktifitas dan menujukkan kemampuan. Merupakan suatu kewajiban orang tua memberdayakan kemampuan atau potensi anak berkebutuhan khusus (Liando dan Dapa, 2007). Data tersebut menunjukkan bahwa orang tua anak DI di SLB Pamardi Putra sebagian besar berperan sedang dalam meningkatkan kemampuan keterampilan menyikat gigi pada anak disabilitas intelektual. Anak disabilitas intelektual yang sekolah di Sekolah Luar Biasa termasuk kelompok anak mampu latih. Orang tua yang peduli untuk melatih anak melakukan kegiatan gosok gigi dapat meningkatkan kemampuan anak disabilitas intelektual dalam melakukan kegiatan gosok gigi. Berbeda halnya dengan orang tua yang peduli untuk melatih tetapi cenderung memanjakan anaknya. Menurut Wiryadi (2011) bahwa orang tua anak berkebutuhan khusus yang terlalu memanjakan mengakibatkan anak tidak mandiri. Harvey (2004) menambahkan bahwa orang tua anak disabilitas intelektual sebagian cenderung over-protective dan bersikeras untuk membantu segala kegiatan anak walaupun sebenarnya anak dapat melakukan. Kecenderungan orang tua yang memiliki anak berkebutuhan khusus, sebagian menghindari kontak sosial dengan anak karena rasa malu serta sulit untuk menerima kenyataan. Prasodjo (1976) dalam kajiannya menyatakan bahwa salah satu sikap yang diperlihatkan orang tua menghadapi 
anaknya yang terbelakang yaitu sikap acuh tak acuh.

Gambar 2 menunjukkan bahwa sebagian besar subyek penelitian keterampilan menyikat gigi pada kategori sedang (52\%). Keterampilan menyikat gigi merupakan salah satu materi bina diri anak berkebutuhan khusus yang diajarkan di Sekolah Luar Biasa. Keterampilan anak berkebutuhan khusus berhubungan dengan urat syaraf dan otot-otot yang lazim tampak dalam kegiatan jasmaniah seperti menyikat gigi (Syah, 2003). Menyikat gigi merupakan salah satu cara mekanis yang paling efektif untuk membersihkan plak gigi (Apiou dkk, 1994). Keterampilan sama artinya dengan kecekatan, terampil merupakan suatu kepandaian melakukan suatu pekerjaan dengan cepat dan bail (Soemaryadi, 1995).

Hasil analisa statistik menujukkan tidak ada hubungan yang signifikan antara peran orang tua terhadap keterampilan menyikat gigi dan mulut anak disabilitas intelektual nilai p : 0,185 $(>0,05)$ (Tabel 2). Beberapa faktor yang mempengaruhi keterampilan kelompok disabilitas intelektual salah satunya karena karakteristik dasar anak disabilitas intelektual yang memiliki kemampuan motorik lamban, keterampilan komunikasi yang kurang serta memahami pesan yang kurang. Selain itu, ketelatenan orang tua yang harus sering terus menerus melatih secara berulang-ulang memberikan dampak pada peningkatan keterampilan bina diri anak disabilitas intelektual (Wantah, 2007).

\section{SIMPULAN}

Hasil penelitian menunjukkan bahwa dari hasil analisa statistik menujukkan tidak ada hubungan yang signifikan antara peran orang tua terhadap keterampilan menyikat gigi dan mulut anak disabilitas intelektual nilai p : 0,185 $(>0,05)$.

\section{UCAPAN TERIMAKASIH}

Penulis mengucapkan terimakasih pada FKG UGM atas Hibah Penelitian DAMAS tahun anggaran 2012. Selain itu juga mengucapkan terimakasih kepada mahasiswa PSHG FKG UGM atas bantuan dalam pelaksanaan penelitian, serta pada guru-guru dan muridmurid di SLB Pamardi Putra Banguntapan Bantul Yogyakarta.

\section{DAFTAR PUSTAKA}

DSM-5. 2012. Diagnostic And Statistical Manual Of Mental Disorders (DSM5). Washington DC: American Psychiatric Association. Selikowitz M. 2001. Mengenal Sindrom Down. Arcan: Jakarta.

Kay, J. dan Tasman, A. 2006. Essentials of psychiatry: Mental Retardation. West Sussex (England): John Wiley and Sons; p.285-93.

Lumbantobing, S. M. 2008. Anak dengan Mental Terbelakang. Jakarta: Balai Penerbit Fakultas Kedokteran Universitas Indonesia.

Idris, Z. dan Jamal, L. 1992. Pengantar Pendidikan. Jakarta : Grasindo.

Notoatmodjo, S. 2003. Pendidikan Dan Perilaku Kesehatan. Rineka Cipta. Jakarta.

Smeltzer. Suzanne, C. dan Bare. Brenda, G. 2002. Buku Ajar Keperawatan Medikal Bedah Brunner dan Suddarth (Ed.8, Vol. 1,2), Alih bahasa oleh Agung Waluyo dkk. EGC. Jakarta.

Apiou, J. Gueguen, M, M. Doleux, S. dan Bonnauerre. Mallet, M. 1994. Evaluation of a New Tootbrush Concept with Regard to Bacterial Elimination. J. Clin. Periodont. 21:347-350.

Sriyono, N. 2007. Pengantar Ilmu Kedokteran Gigi Pencegahan. Yogyakarta. Medika Fakulltas Kedokteran UGM.

Kumar, S. Sharma, J. Duraiswamy, P.1. Kulkarni, S. 2009. Determinants for Oral Hygiene and Periodontal Status Among Mentally Disabled Children and Adolescents. J Indian Soc Pedod Prevent Dent. Vol 27.

Loureiro, A. Costa, O. Da Costa, E. 2007. The Impact of Periodontal Disease on The Quality of Life of Individuals with 
Down syndrome. Down Syndrome Research and Practice. Vol 12.

Istiqomah, F. Susanto, H.S. Udiyono, A. Adi, M,S. 2016. Gambaran Karies Gigi pada Anak Tunagrahita di SLB C Kota Semarang. Jurnal Kesehatan Masyarakat. 4 (4): 359-362.

Southern Association of Institutional Dentist (SAID). 1995. Preventive Dentistry for Persons with Severe Disabilities: In Self-Study Course. Module 11. 21-24.

Subekti, R. dan Firman, H. 1986. Buku Materi Pokok Evaluasi Belajar dan Pengajaran Remedial. Universitas Terbuka. Jakarta.

Timmrect, C.T. 2005. Epidemiologi Suatu Pengantar. Jakarta: EGC.

Liando, J. dan Dapa, A. 2007. Pendidikan Anak Berkebutuhan Khusus dalam Perspektif Sistem Sosial. Departemen Pendidikan Nasional. Direktorat
Jenderal Pendidikan Tinggi Direktorat Ketenagaan. Jakarta.

Wiryadi, S.M. 2014. Pola Asuh Orang Tua dalam Upaya Pembentukan Kemandirian Anak Down Syndrome $X$ Kelas D1C1 di SLB Negeri 2 Padang (Studi Kasus di SLB Negeri 2 Padang). Jurnal Ilmiah Pendidikan Khusus. Hal 737-746.

Harvey, J. dan Delfabbro, P.H. 2004. Psychological Resilience in Disadvantaged Youth: Critical Overview. Australian Psychologist.39 (1), 3-13.

Prasodjo, T. 1976. Gangguan Psikiatrik pada Anak-Anak dengan Retardasi Mental. Disertasi. Surabaya : Universitas Airlangga.

Syah, M. 2003. Psikologi Belajar. Jakarta: PT. Raja Grafindo Persada.

Wantah, J. 2007. Pengembangan Kemandirian Anak Tunagrahita Mampu Latih. Departemen Pendidikan Nasional Dirjen Pendidikan Tinggi Direktorat Ketenagaan. Jakarta 